\title{
On Pina Bausch's Legacy: an interview with Dominique Mercy
}

Dominique Mercy

Tanztheater Wuppertal Pina Bausch - Wuppertal, Germany

Marcelo de Andrade Pereira

Universidade Federal de Santa Maria - UFSM, Santa Maria/RS, Brazil

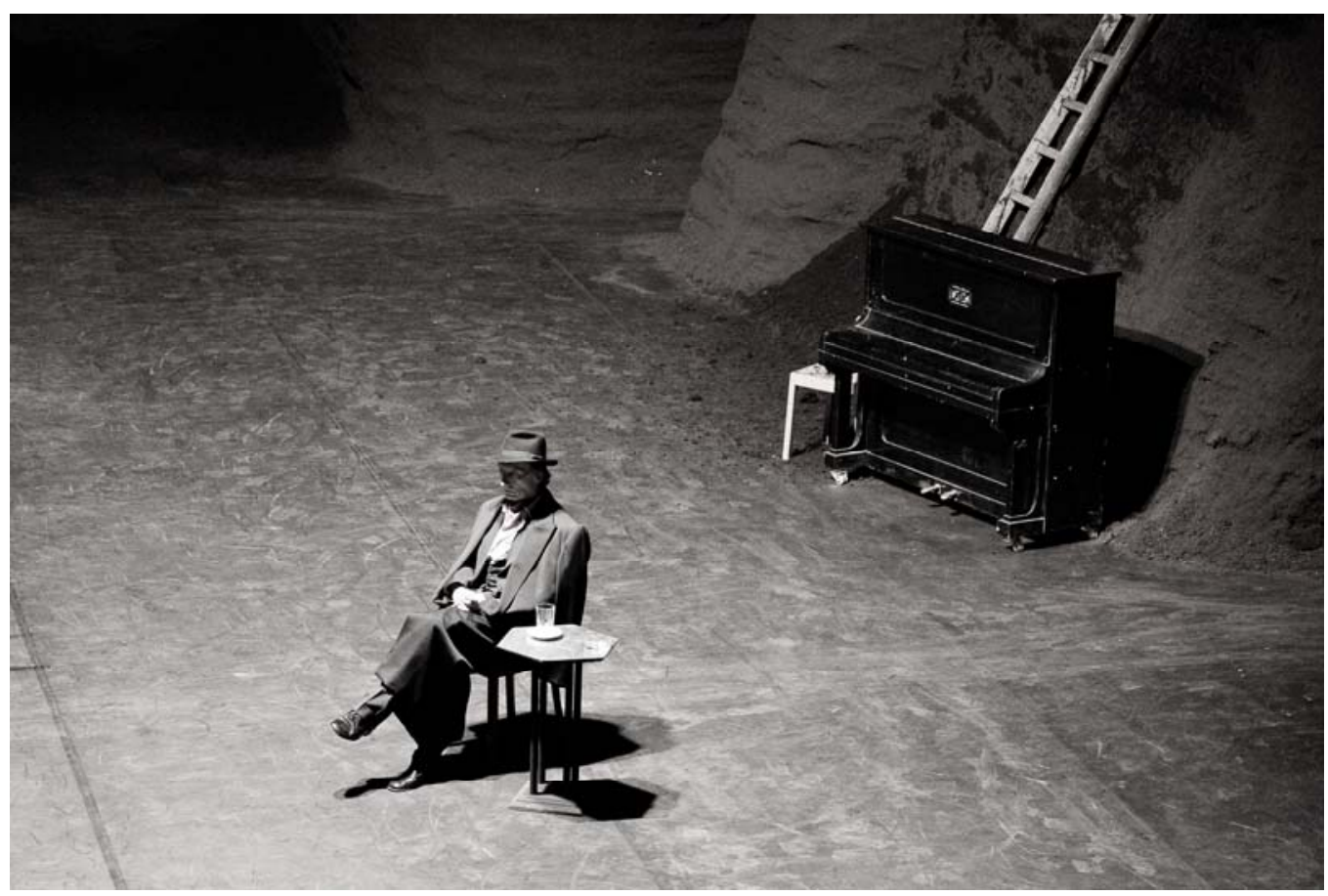

Image 1 - Dominique Mercy, on Viktor, Tanztheater Wuppertal Pina Bausch. Source: Photo by Jochen Viehoff.

Pina Bausch's pieces are her dancers, but each dancer is Pina Bausch. It is not that they take her as a model and mimic her. Each one is one-self, but they would not acquire identity without Pina Bausch's look, marking, makes sense of their movement and puts them into relation with the whole being built (Sasportes apud Galhós, 2010, p. 73).

Perhaps no other author has better characterized the work of Pina's dancers - and, therefore, the artist's herself - than José Sasportes - a remarkable Portuguese dance critic and historian. This brief observation of Sasportes, made in a text entitled Acção para bailarinos [Action for dancers], and regarding an event held in Lisbon in honor to Pina Bausch, allows to 
perceive in quite clearly the meaning of the experience and legacy of a remarkable artist, that are summarized in the figure of one of her greatest collaborators, Dominique Mercy.

Certainly, there is no need to introduce Dominique. It is worthy, though, to recover some moments that preceded his fortuitous encounter with Pina in the early 1970's in Saratoga, United States. Born in 1950 in the city of Mauzac, France, Dominique's first professional steps in the dance world from the mid-1960's on were in the Bordeaux Grand Théatre, later followed by the Amiens Ballet du Art Contemporain. In 1973, two years after his first encounter with Pina in the Summer Festival of Saratoga, in 1971, Dominique goes to Germany, to Wuppertal, to be part of the recently founded Tanztheater.

His close relationship with Pina allowed, in fact, that her legacy could be kept alive following her sudden death in 2009. Dominique took over the artistic direction of the Company with Robert Sturm for some of the following years, having later transferred the position to his co-worker and dancer Lutz Forster. It was beside Pina and so many others from the Wuppertal ensemble that Dominique ended up writing one of the major pages in the annals of dance history in the $20^{\text {th }}$ century.

The experience of - or rather, with - Pina that each one of us apparently has with her when meeting her work for the first time, allowing to understand in a certain extent the fascination that she exerts until nowadays on the audience, passes as well and indispensably through those who worked with her and by her means. My first time with Pina was, for sure, beside Dominique Mercy, or rather, in front of him. Dominique was half-naked, wearing only a tutu and carrying a watering can. It was 2006, for the presentation of Fur die kinder von gestern, heunte und morgen, in Porto Alegre. Pina was also there.

The unusual encounter - even though separated by the proscenium arch - would happen again years later in Paris. However, this time, in 2011, without Pina and with no line dividing us. I was introduced to Dominique following one of the presentations of Como el musguito em la piedra..., by the also Tanztheater Wuppertal dancer Daphnis Kokkinos. On that occasion, Dominique had an extremely light and welcoming attitude. Over the years, I noticed that it was not a protocol way of introduction, but 
the very donation of part of what he was, how he was, not in a way, but in his way, with or without tutu. In January 2018, when recollecting that encounter with Dominique in his house in Barmen, Wuppertal, he did not remember it. And he certainly could not, as I, absorbed in my amazement, had articulated little - or nothing - at that moment. However, even in my involuntary contemplation, something had been given to me, a long-lasting presence.

It was according to Dominique's generous, honest and delicate way that this interview actually happened. I thank him for the attention and for the coffee. I also thank my dear friend Eddie Martinez, who made this and so many other happy encounters possible to me.

Marcelo de Andrade Pereira - Would you tell us about starting to work with Pina? How was this beginning?

Dominique Mercy - Well, nobody thought and knew that we were going to be part of dance history. I met Pina in The United States because by chance, if chance exists, she was invited by Paul Sanasardo for a summer academy in Saratoga Springs. Maybe you know this story. She was invited by him to take part in the teaching process, to teach, to revive and to study one of his choreography for the company there, and also to dance herself. She danced a solo based on Pierre Henry's music.

For my part I was invited by one of Paul Sanasardo dancers, Manuel Alum, whom I had met in France. The company I was working with at that time had invited him. He was teaching there and we sort of connected and understood each other quite well. Somehow his teaching, his personality and our chemistry were a big revelation to me. Malou Airaudo was also very much involved because she had left a company and was also working with Manuel Alum.

In the summer of 1972 he asked if I could get in the frame of the summer academy he was having besides the work he was doing with Paul Sanasardo. He had his own company that was made of mostly Paul Sanasardo's members and dancers but there were also some guests. One evening he told me he was doing a new little piece in Saratoga and he asked me if I could come because he wanted to work with me, but I had no clue about Pina, I didn't talk about Pina, which was not the purpose. I was just on vacation 
and I didn't have any plans. I had never been in The United States and I thought why not. I thought it would be a beautiful opportunity to do different things. When I arrived at the Greyhound bus to Saratoga it was quite late in the evening. It was nice. Three people were waiting for me: Manuel Alum, Malou Airaudo and another young lady whom I didn't know. I first thought she was the sister of Manuel because she had a similar type of bony face. But it was Pina. Then the dancers and students were sent to different houses; they had beautiful houses in Saratoga. Malou, Manuel, Pina and I were sent to the same house. So even before anything artistically or work related we sort of became friends and got to know each other. I didn't speak German, Pina didn't speak French and at the time she probably spoke better English than me. Even then, we were able to communicate to each other, we had a different way of communicating. In the beginning I was very impressed by her class and her dance technique. I actually didn't know about it although I was European and lived close to Germany - I had never been taught or confronted to this Kurt Jooss or Jean Cébron or this side of European dance. For me the movements were a big discovery. I felt it was something very close to me, I somehow felt like I recognized something that I didn't know. On one side I saw the work that she was doing with the company; I think it was the piece with only women. I forgot the title now. I was very impressed because I saw all these strange movements that I really liked. But above all she as a dancer and artist mostly impressed me. When she danced her solo performance I was completely in awe and felt again very close to it. I felt that it was something I belonged to. And I knew it was a very beautiful experience and we really connected. At one point in the kitchen of our house in Saratoga I remember she told me that she would eventually have a project in Germany. She asked if I would like to work with her and I said: yes, sure. But I didn't know anything. You know, when you have a project you are a bit superstitious and you don't talk too much about it. She didn't go into details; she just wanted to know if I would like to work with her. We left Saratoga and we went to New York for a little while; and then I came back to France with all these experiences. I mean, with everything included - the artistic side of Pina, Manuel, the atmosphere and just to be in The United States at that time. It was 1972 and there were many things going on. I also 
saw all these different people dancing. Of course it was Pilobolus, Paul Sanasardo, Antony Tudor. I saw many other people and things-it was a very strong experience.

When I came back to France I knew I couldn't just keep on working in the company I was in. At the time I was in the ballet du art contemporaine in Amiens. When I came back to Amiens, I told them that it would be my last season. So that was it. I had no plan. I just knew that what happened to me gave me a feeling that other things should happen, rather than what I was doing there. And shortly after this I received a letter from Pina. She asked me if I remembered the project that she was thinking about. Malou had already said yes. Pina asked me if I would like to join her and told me that she was going to have a company in Wuppertal, Germany. She asked me if I would like to do it. And for me it was obvious. I mean, yes. Then at the end of the season I left France and I came to Wuppertal in the summer. It was August. So I arrived in Wuppertal with no idea what to expect, except that Pina was there. I didn't know her very well. I mean, I knew that we were expanding together. The time we spent together had an impact on me. But I had no idea if it all would work out - I had only had classes with her. During that time in Saratoga she already had a lot of back problems due to the movements. I only knew that it was not easy for her. I didn't expect anything. We just started with the first piece. The first evening was a three bill evening, with The Green Table, from Kurt Jooss. Of course it was a big step into this technique and all this part of European, this German dance was a big discovery for me - to know the teaching Hans Züllig and all Jean Cébron, for me the Hans Züllig specially, and of course Jooss without really knowing all this big history.

So there was The Green Table from Jooss and there was the Rodeo from Agnes de Mille - another part of a big history of Eastern dance that I didn't know either. It was fantastic because she was there for quite a while. We also met Agnes de Mille and worked with her. It was a lot of fun. There was this piece from Pina called Fritz. Fritz was the first piece that she did in Wuppertal; a very strange piece. It was a story about a little boy and his family; a father, a mother and a grandmother. At one point they would somehow become a sad family. It was not a happy family. It was like a lost dream. The little boy was in the middle of these three family members. At 
one point a fantasy atmosphere would take over and the room would get bigger. There would be a big procession of very strange guests; there were twins, a woman with a beard, a woman who was a lamp, a table lamp and umbrella, a woman with long, enormous arms and a woman with no hair wearing a long dress and a young, sick and strange guy in a night shirt which was me. For me it was an incredible experience. For the first time I had a true and real sharing with the choreographers. They were working with me as I really was, in a very personal way. I had a little cough so we somehow worked on that to create a dance. Then everybody was coughing as well. For me that was a very strong and beautiful experience. And it motivated me. During the same season we made the first Gluck 's opera, Ifigenia auf Tauris. It was like a big present, a big gift, because the music was so beautiful. I love this music and I love all the singing. We communicated and worked together beautifully. We were doing this together. A lot of choreographers had been doing this for a long time. But for me it was a very special and intimate experience.

Marcelo de Andrade Pereira - How did the audience respond to those pieces at that time?

Dominique Mercy - I think there were different kinds of audiences. First of all we had to cope with the ballet audience in Wuppertal. They had a very classical ballet company before Pina and for them it was like putting it upside down. It was like they didn't know what to do with all of this. Pina was so different and I think that even pieces like Rodeo and Green Table were for them. They had ballet repertories for many years. I remember when all this began it was actually very difficult for everybody. Especially for Pina because she had received strong letters and behaviors, like telephone calls. At one point she thought that her life was really in danger; it was very strong. We started with a very small audience and finished with an even smaller audience. I don't know how small. It was quite difficult. At the same time there was another audience, a mixed audience, people who were already interested in our work. And there was this other audience that probably came from the opera. It was not the same audience from the ballet. At that time there were all these abonnement and things. There was probably a big opera audience for Ifigenia auf Tauris. During this piece the singer was in the audience, on the balcony and the chorus was also in the 
audience. It was just the dance on the stage and right away it was a tremendous success. So somehow we had those two opposites for a certain amount of time. After, the next season we did Mahler... a piece where we were all singing. There was no music except us singing; there was another piece of Kurt Jooss, and Orpheus und Eurydike, from Gluck. So we kept on going on these two levels: on one side an incredible success with this opera and on the other side a very difficult audience.

Marcelo de Andrade Pereira - What kept you in the company considering all this difficulties?

Dominique Mercy - Well, there are a lot of things because there were somehow different aspects; reacting to theses difficulties there was something among us something because as far as I remember - because all this years covering all of this somehow - because neither she or we thought that we were doing something extra to provoke or trying to provoke the audience or looking for something strange.

It was just the natural way of searching, looking for a language, for a way to say something, to put us on the stage, to share those things; we thought we were on the right path somehow. There was no question. I think it was probably much more difficult for Pina because in the end she was responsible for all this and we didn't have that responsibility. I mean, we were sharing and working together but it was literally not on our shoulders.

Marcelo de Andrade Pereira - But some dancers left the company at that time, right?

Dominique Mercy - So did I (laughs). There were different reasons; it's true. I think it takes time to find them, like in many other companies. Even though with all this work there were some doubts. I have always a lot of doubts and I ask questions to myself. I didn't fight but I almost argued with Pina because we didn't agree about certain things, maybe because we didn't understand each other. There was always a sort of struggle within the company. It went so far when I left the company. I think it was a time with a lot of doubts. Jo [Josephine Ann Endicott] can probably tell you more about it, because she was there. I had left and I just came to see the performances or to make other performances as a guest. There was a time when it was so difficult. Pina had so many problems with the company. 
One day she said: ok, who wants to come and work in the studio? There was a moment where she even left the studio to work and she went to another place in Wuppertal which I think it was Jan Minarik's studio. He had a dance school in a house in Barmen, and Pina went there to rehearse. There were just two, three or four people and slowly by slowly people came back and they finally did the piece together. It was not easy with the audience but also within the company. There was another layer for me since I had started very young or quite young. I had my first season when I was 15 . So when I entered Pina's company I was almost 23. There were all those years for a young person from 15 to 22 . I never regret it but very early I was sort of taken by a very strict schedule and discipline: the class, rehearsal, break, rehearsal, class, break, rehearsal, break, rehearsal, class, dum, da rum da ra da ra... So for a while it was completely normal and obvious but at one point since then I've had all that struggle. I've never figured it out. I felt I needed some air because I had jumped from the theater I had started to one company and from that company I jumped to Wuppertal. I've never had like many young dancers have guessed being in a bigger city, taking the class I wanted to take, not the company class but going to a teacher with other people. So I need to be able to see performances, to be in a bigger city, to be in a sort of stormy world.... I felt I needed to get rid of this schedule, this rhythm and to have more.... So that was the main reason I think we left. Because Malou also left with me at that time, we were very good friends at that time. So I left. I didn't know what I wanted. I just knew I wanted to be in a bigger city. So I didn't go back. I went to Paris and stayed in Paris.

Marcelo de Andrade Pereira - So when did you get back to Wuppertal?

Dominique Mercy - I came back to the season of 1978. There was still this struggle although it was a very rich season because we've had started the season with Renate wander aus, which was also a charming piece after Bluebeard. She was looking for other things and also with text a little bit. There was a lot of improvisation. When we did Renate she went with a few of us to Bochum which we right away we had this first co-production with the Macbeth piece Er nimmt sie an der Hand und führt in das Schloss, die anderen folgen. A very long title which is a sentence from Shakespeare's Macbeth. And it was also an incredible time because she also did Kontakthof. 
I wasn't there when she did it, but that's when she started making very simple questions or asked to do a simple movement or to be in a very simple mood. Then she kept doing this plus adding other type of questions referring from what inspired her from Shakespeare, from the story of Macbeth. It was a very rich and creative time but with struggles, a lot of doubts and questions as well. When we came back after this I had taken my decision, so had Malou, to leave the company again. I don't know, there was something in the atmosphere of the company or the struggling. Something that made us react or maybe to quit, not to quit, whatever! I don't know... It was amazing though because Pina knew that we were leaving. For a while it was not easy because we had a very strong relation and when friends leave you it always hurts. Nevertheless it was something I didn't realize at the moment. But afterwards I understood and I was like, wow, this is really incredible and so generous. Nevertheless she knew we were leaving and she asked us to be part of it.

At the same time it was the work of a Macbeth piece. Since we were a few dancers she had an idea with Rolf Borzik who was her companion and a set designer to start an evening with other choreographers. So she invited an assistant, Hans Pop. There was a young Romanian French choreographer Gigi Castigliano and Gehrard Bohner, he was a contemporary German choreographer. So she asked them to work with the company to make three different little pieces and they had this idea to find a thread... to sort of going through all the pieces, to have a man with his glasses, a coach and chairs, a woman with a red wig and red shoes as well. Something that you could find in each piece, going through the evening and completely free how to use it. So when we were doing the Macbeth piece they were working at this and when we came back from Macbeth Pina asked Malou and me that she would like to add a little piece to this evening, if we would like to. She knew we had some problems with other dancers and things but she said: - I know the situation, that it's a little bit tight and that you're struggling, would you accept to do it? And we said: yes, of course. And that was Café Muller.

When you think about it it's actually just amazing to be able to make such a step knowing we were leaving and being able to try something as beautiful and strong as Café Muller without knowing that it would be Café Muller. 
That was a very strong experience. But nevertheless we left after because I was having a serious crisis. I really thought I didn't want to do anything with dance. I wanted to quit. I was strongly interested into singing but I didn't make the steps to really study in a school or academy, something that had to do with singing. I was taking classes though and tried to work with my voice. But there was a time that I thought I didn't want to dance anymore.

Marcelo de Andrade Pereira - What did you do then?

Dominique Mercy - So I left Paris and went to south of France. And at one point I was at the countryside and I realized: no, I need to go back, I belong somewhere else even though I love gardening, the earth and the countryside, but I felt something... so I went back to Paris and it was beautiful because both times, the first time we were there, Malou and I that's when I've met Carolyn Carlson. For me it was a very important encounter. She had a small company belonging to the opera, a sort of Research Company. I forgot the exact name of it. She was working with a new piece and it was so beautiful because some of the dancers that we met in New York had left the city and came back to France like Jan Patarrosse, Dominique Petit, Chris Valjean. These people worked with Paul Sanasardo at that time. So when we left Wuppertal we met again there. Two of them were working with Carolyn Carlson. Malou and I went there. Malou didn't switch right away, but after yes, I felt very confident. I really liked it very much because it was also very airy and something new for me, a new door to go through. It was a very beautiful and important experience and she asked me if I would like to join the company. I said: I'm sorry, I really liked to work with you Carolyn, but I'm sorry. I've just left a company and I don't want to get involved with another one. I was very happy and she kept me in the project. I was very happy for it, but I didn't feel I could sign a contract and get involved in the company, so I refused it. But it was the first time we left with two dancers and we started to have fun together. We spent some time at the studio to be creative. We made a little group there and we had our own work and started performing. It was not easy but it was fun. So, when I got back to Paris the second time, for the second period, which was the last season when Carolyn Carlson was at the Opera. She asked us and wanted us to participate in the last piece for the Opera, 
which was the architect on the Bach music. So for me it was another way to step in to dance again. It was very nice. But then I went to see Pina's performances at Theatre de la Ville. I realized that's where I belong. That's where I feel... yeah, my place is there, by Pina; this is where I belong, yeah. That was also the good part of going away. I could see performances; so I saw performances that also helped me to understand things that are not so obvious or things you struggle with, within the company.

Suddenly I saw the piece from the outside and from the outside I saw what I eventually was inside. It made me realize this is where I have to be. So I went back to Wuppertal. Each time there was so much generosity even though she met us and understood that it was difficult. She hadn't been happy for us to leave but she opened the door again. We were able to come back which was not so obvious. That was in 1980 .

Marcelo de Andrade Pereira - So, now I'm going to the second round! We know that you became artistic co-director of the company with Robert Sturm when Pina died. Could you tell us about that moment? What happened in those days?

Dominique Mercy - It was difficult. In the first place I didn't... It was difficult because it was of course a huge responsibility. I didn't feel I would have the strength to do it alone. That's why I asked Robert Sturm to do it with me. But the most difficult part... I don't know if it was a good idea... but I though, if I dare to try I need somebody with me who could combine the studio work, the artistic work and the organization. We failed a bit on this because we didn't really organize our responsibility, if I could put it that way. We tried our best, of course... maybe that was, probably, I mean, to be... honest and objective if objectivity exists at all. That was probably the way we had to go, but it was very difficult. Apart from the big responsibility it was very difficult because of ... until now... until that time I was always... ok.

I've always been very close to Pina and people would tell me I could... or they send me to her and tell that I should tell... you know something which didn't work or people want to say something to Pina but they didn't dare.

Nevertheless I was a dancer within the company with other members of the company. Suddenly I was also a director, it was a very awkward situation. 
Pina had this capacity to have a very strong connection with each one of us. That was very beautiful and probably made it possible for the company to survive. Everybody felt a responsibility. But this also meant that everything would be put into question. So it was very difficult to take initiative or to find a way to be democratic in the company. It had never been democratic because whatever happened Pina somehow was always the big pole, the center of the company. Everything would come from her or to her somehow. And suddenly it was sort of the same structure but not at all comparable. It was very difficult and at one point there were a few obstacles or storms on the way. And at one point the storm was bigger than the other one. I decided then to quit, to step back and to just be a dancer again. Try to bring what I could bring as a dancer with my history, my memory or whatever. Try to be part of this but not being responsible anymore. It was too much. Try to dance, try to have all this responsibility, all these feelings, sensitivity, demands and expectations. Yeah, it was too much.

Marcelo de Andrade Pereira - With Pina's death several dancers left the company. So, it was necessary to reorganize the work?

Dominique Mercy - Oh, yes and no, because people are constantly leaving the company, starting with me somehow, not starting but belonging to those people you know. There are some dancers like me, for instance Nazareth Panadero, Josephine Ann Endicott, Helena Pikon who left the company and also came back. Some people had left the company and never came back. Or they were guests depending on the performance because Pina still wanted to have that specific dancer belonging to specific pieces. So very early on all of us had to cope with all this casting changes or new people coming. It was for a certain time very good for the company because it was really enriching. At the beginning of the company we were more or less the same generation and the same age. With time when new dancers came to the company the gap would be even bigger. So it was very nice at a certain point to have younger dancers who gave different energy or different movement quality. It was also very enriching for Pina. It brought new things, new qualities to always cope with and to have new members. For a certain times she never worked with the old company. It was too much. She was trying to combine different cast. Some of us were doing all the pieces but some of us were also being part of one piece and not the next season or 
maybe two seasons in a row and not the next season. But you always had the instinct to create, the feeling to somehow continue. For a few years when Pina left we tried to invite and to find a way to continue to be creative. We also tried to invite either choreographers or theatre people.

Marcelo de Andrade Pereira - And how was it?

Dominique Mercy - It was probably too early and it didn't work out. So the creativity was missing and it was very understandable that some people would want to leave and have another creative life or other dynamic work. Because we didn't know yet where we would go. And that was probably also one of the big challenges and all of struggle after Pina's death. One side of this was a very strong wish to be together and try to keep the company. We also had the big chance. Right away the city told us: don't worry, we'll be backing you up, there will be no restriction, we want the company to keep existing. That was a very generous and a big support from the city because we didn't have to fight for this after Pina's death.

Marcelo de Andrade Pereira - As we know it Pina used to choose her dancers. After she left how were the new dancers chosen?

Dominique Mercy - Well, at one point when some of the dancers really decided to leave we had to make an audition. I don't remember when we did the first audition. It was probably in 2012 or the season 2013. So we organized ourselves. We decided to have a bunch of us to try to mix the sort of historic dancers and some new dancers to try to mix and to make some committee to organize the audition. It went very well actually because we realized that somehow even though you sometimes have a different test or different feelings for a person we had sort of edited eyes and senses. At the end we realized that. At one point you feel this person is the right one. That's how we function. Robert Sturm and I quit the direction of the company. Then we asked Lutz Forster to take over it because we were willing to make a change anyway. So we were already organizing the venue of Lutz with us within the company. We asked him to take over and that's what he did for three or four years. Then we also made an audition with the same principle. Maybe it wasn't so expanded because too many people went there. It's difficult to come to a decision. Seven or eight of us somehow, including Lutz, had a last meeting to try to decide which dancer would be 
taken to the company. And there we still had the idea of a repertoire that is somehow not easy and a little bit different.

Marcelo de Andrade Pereira - How's the relation with the old generation and the new one? How does it work?

Dominique Mercy - I think it's different for each one of us. I think it has to do with the loss of Pina. For me it has never been a problem. I always liked to welcome new members in the company and I've never felt this sort of distance between old or older and young or younger. It was somehow never a deal or a concept for me. At the end we think that the richness of the company is this mixture. But at the same time without Pina being there, since there was this legacy left in a certain bunch of dancers, which been there for so many years, without knowing it became a little bit the old and the young, and the new, maybe unconsciously something was sort of like to be felt or seen specially by the young people.

There was a certain amount of time that felt a little bit strange. But I think now, with all that has happened and the fact that there is a new artistic director, Adolphe Binder, we have more organically come to a time when we have to pass things on. Slowly by slowly things depend on the piece and are becoming even more demanding, like sort of physically difficulties. You have to realize that with the years there are some pieces that we were creating and we were already aging. So it's a little bit different but we still do pieces that we created when we were much younger. But there's something beautiful. I think it is also very unique that we are able to do this journey, this time journey through the repertoire. There are limits though even if you don't want it. And you have to consider and to see them, to feel them in terms of being at peace with yourself. So it's happening much more since there are something going on that is more together, a more organic role passing and sharing. I think it is a little bit different; it has to be a time when you could feel this sort of gap between the two groups.

Marcelo de Andrade Pereira - If you could sum up Pina's legacy for dance, what would you say?

Dominique Mercy - Oh my goodness! What could I say? It's a difficult question because there are so many things to consider or to involve. I mean, above all there is this honesty in the searching. There is this constant searching even though people say, or you sometime feel, she's staying in the 
same pattern. But you can see from piece to piece or block of pieces.... even if you can't explain or point out....Maybe there are clever people everywhere who are able to point out or explain, but I can't. But you can feel there are different steps. So there is this constancy in all the searching and in the trying to go forwards. Always go further somehow. I don't know what the most important is but there is this connection without being didactic or intellectual. Pina was everything but intellectual. She never made decisions on the conceptual level. She was always the first audience and it had to mean something and to move something. Most of all it had to last even though sometimes she would say: ok, this piece is what it is, it's been made, I cannot touch it. There are some pieces she wanted and she did change things. So she continued to work to make us as efficient as possible. The last year she was willing to take and change some older pieces, something she felt were too long or too much repetition. Things she thought not needed. She wanted sort of clear, she didn't go there but she wanted it to somehow. What made it so alive was probably her way to share and to look at the human being, I think. To look inside of the human being from outside, to be concerned with all that we are being concerned with, that we are copying with the struggling, asking for and to try this. Try to find a language within all this. Try to find a form but including this look into humanity. Because when you look at some of the pieces, even though it was never a direct subject, she was always very concerned by the world around us. That's why I said outside and inside the human being. When you look at some old pieces they are so... nowadays the theme is so actual, the form is still the right one; when you see some pieces and you realized when they were done and you look around a bit what you see on different stages or different companies or choreographers nowadays and you realized... the gap is so big and even though Pina is so accurate, so today, so modern somehow. Of course you can probably feel study, there are things that are dated but if you look at the work altogether, the weaknesses, the strong, it's just amazing... you feel it when you are in the audience. You somehow feel it when you are on the stage, within the time. But when you sit in the audience and your stomach... what you feel...

I go to so many performances and I always try to find a positive side. But at the end there is so little that is left in me, what I take with me. But, when 
you sit out there and look at a Pina piece it's just amazing because it's so... you really get... there are no piece you don't fell personally concerned at one moment or the other and that's what you are looking for, somehow.

\section{Reference}

GALHÓS, Cláudia. Pina Bausch - ensaio biográfico. Lisboa: D.Quixote, 2010.

This unpublished text is also published in Portuguese in this issue.

This is an open-access article distributed under the terms of the Creative Commons Attribution License 4.0 International. Available at: <http://creative commons.org/licenses/by/4.0>. 